\title{
QUEEN'S
UNIVERSITY
BELFAST
}

\section{Christmas television}

Johnston, D. (2018). Christmas television. Journal of Popular Television, 6(1), 81-84.

https://doi.org/10.1386/jptv.6.1.81_1

Published in:

Journal of Popular Television

Document Version:

Peer reviewed version

Queen's University Belfast - Research Portal:

Link to publication record in Queen's University Belfast Research Portal

Publisher rights

(C) 2018 Ingenta.

This work is made available online in accordance with the publisher's policies. Please refer to any applicable terms of use of the publisher.

\section{General rights}

Copyright for the publications made accessible via the Queen's University Belfast Research Portal is retained by the author(s) and / or other copyright owners and it is a condition of accessing these publications that users recognise and abide by the legal requirements associated with these rights.

Take down policy

The Research Portal is Queen's institutional repository that provides access to Queen's research output. Every effort has been made to ensure that content in the Research Portal does not infringe any person's rights, or applicable UK laws. If you discover content in the Research Portal that you believe breaches copyright or violates any law, please contact openaccess@qub.ac.uk. 


\section{Dossier}

Derek Johnston

Queens University, Belfast

\section{Christmas Television}

Introduction

Whereas we have little idea of how the majority of people in Britain were spending their time at 8 p.m. on Christmas Day in 1884, we do know that at the same time one hundred years later, over $70 \%$ of the population were watching television and that of these nearly 20 million, or $37.5 \%$ of the population, were watching one film, Raiders of the Lost Ark. (Golby and Purdue: 105)

As Golby and Purdue so clearly point out, television is a central part of the British Christmas. It is written about in the newspapers, the listings magazines produce 'legendary’ double issues (to quote the now regular strapline from the cover of the Christmas and New Year Radio Times). It provides a focal point around which to gather the family. It is marked out as different from the rest of the year, yet at the same time familiar, as a repeated interruption to the annual schedule.

And yet Christmas television has had little academic attention. Golby and Purdue’s mentions aside, there are a handful of articles and book chapters considering the broadcast season and its programming, such as Christine Agius' chapter on 'Christmas and War' and Tara Brabazon’s ‘Christmas and the Media’ in Sheila Whiteley’s Christmas, Ideology and Popular Culture (2008), Robert J. Thompson’s chapter ‘Consecrating Consumer Culture: 
Christmas Television Specials’ (2005), or Diane Werts’ Christmas on Television (2006). The previous special issue of this journal dedicated to seasonal television (volume 5, number 1) contained three out of six articles which focused at least in part on Christmas as opposed to any other broadcast season. Each of these publications takes a very similar basic view of Christmas television, one summed up by David Budgen in his consideration of Doctor Who (1963-1996; 2005-) Christmas specials, that Christmas television 'is often frivolous, appealing to a broad audience, conveying a warm sense of nostalgia rather than cutting-edge entertainment' (91). That chapter on Doctor Who apart, these considerations of Christmas television frequently focus on the US experience, and one of the interesting aspects of examining seasonal television in the round is the way that it reflects its native culture; despite the similarities, there are many differences between a US television Christmas and a UK one.

Looking historically, the television Christmas in the United Kingdom has developed a number of different traditions, some of which remain, like the broadcast of the Festival of Nine Lessons and Carols from King’s College Cambridge (since 1928 on radio), or the monarch’s Christmas speech (since 1932 on radio), or the Royal Variety Performance (since 1925 on radio), or the Royal Institution Christmas Lectures (since 1936). Some traditions seem to have disappeared, or at least faded significantly, including the production of television pantomimes, the broadcast of a circus show, the promotion of 'the big Christmas movie', and the connection of broadcasting and seasonal ghost stories (see Johnston 2015). Much of this programming and scheduling has received little attention, particularly in looking at the larger patterns, such as the more prominent scheduling of 'high culture' material such as ballet and opera on British television in the Christmas season, which appears as a trend rather than a particular recurring programme or specific feature.

This dossier leaves much of this material to be explored at a later date, but instead uses three particular case studies to open out some of the particularities of Christmas 
television in the United Kingdom. Andrea Wright considers the Downton Abbey (2010-2015) Christmas specials in light of their reception both in the United Kingdom and the United States, demonstrating the importance of seasonal scheduling in the perception and understanding of programmes. With the different broadcast schedules of the United States and United Kingdom, these Christmas episodes stood apart from the rest of the series in the United Kingdom, and so were perceived as special events, while in the United States they were joined to the rest of the series, and so were perceived more as continuations of that season and particularly as season finales. Wright's investigation thus highlights the different expectations of seasonal specials and season finales, demonstrating the ways that seasonal specials are not only permitted but are expected to be somewhat different from the norm, in the same way that holidays such as Christmas act as a disruption of the norm in our everyday lives. In so doing, this research also demonstrates some of the issues which have to be negotiated in creating programming for international audiences, negotiating the different expectations associated with different times of the year and with the position of episodes in relation to the rest of the season.

The importance of the seasonal scheduling to the frameworks in which programmes are interpreted also forms part of my article, on the presentation of landscape in the BBC Ghost Story for Christmas (1971-1978, 2005-2006, 2015), and its connection to notions of national identity. While the use of the landscape within these productions is not entirely unusual within television ghost stories, the presentation of these dramas within the liminal period of the Christmas schedules emphasises the liminal nature of the landscapes, particularly woodlands, that they represent. In turn, this enhances a sense of instability and a questioning of connections between landscape and national identity that are often taken for granted, in particular the associations of woodland or the landscape of East Anglia with a sense of Englishness. The article also raises ideas about the representation of the seasons 
through the natural environment in broadcast productions, and how that influences audience interpretation and experience of the dramas.

Christmas is typically associated with family and gift-giving, and with the expense that is associated with this and the resulting displays of economic and cultural capital. The idea of creating handmade items for friends and family, and as part of the Christmas decorations, has grown as a way of presenting a sense of individuality to the celebrations, at the same time as crafting has become increasingly important as an economic activity within the United Kingdom. In her article, Helen Warner explores the interactions of gender, class and economics in the frameworks of government policy through an examination of Kirsty's Crafty Christmas (2013). She demonstrates the ways that the programme devalues the work of the amateur and small-business crafter into essential, unpaid domestic labour, despite making claims to promote crafting, while promoting larger-scale businesses.

Together, these articles engage with a number of the key ideas that have formed the common understanding of Christmas television as domestic, nostalgic and family-centred. However, they demonstrate that this understanding, while not without truth, is one that can readily be complicated. The articles particularly point to the often-neglected aspect of national identity as significant, not only as contained in narratives, but also as transmitted through government policy, through industrial decisions, and through the very decisions made in constructing seasonal schedules for broadcast. Christmas television itself may be a box of delights, but these articles go some way to demonstrating that there are many neglected treasures there from an academic perspective as well as that of the viewer.

\section{References}


Agius, C. (2008), 'Christmas and War', in S.Whiteley (ed.), Christmas, Ideology and Popular Culture, Edinburgh: Edinburgh University Press, pp.137-148

Brabazon, T. (2008), 'Christmas and the Media’, in S.Whiteley (ed.), Christmas, Ideology and Popular Culture, Edinburgh: Edinburgh University Press, pp.149-163

Budgen, D. (2014), “"Halfway Out of the Dark”: Steven Moffat’s Doctor Who Christmas Specials', in A. O’Day (ed.), The Eleventh Hour: A Critical Celebration of the Matt Smith and Steven Moffat Era, London: I. B. Tauris, pp.89-105

Golby, J. M. and Purdue, A. W. (2000), The Making of the Modern Christmas, Stroud: Sutton Publishing.

Johnston, D. (2015), Haunted Seasons: Television Ghost Stories for Christmas and Horror for Halloween, London: Palgrave.

Thompson, R .J. (2005), ‘Consecrating Consumer Culture: Christmas Television Specials’, in B. D. Forbes and J. H. Mahan (eds), Religion and Popular Culture in America, Berkeley and Los Angeles, CA: University of California Press, pp.44-55

Werts, D. (2006), Christmas on Television, Westport, CT: Praeger.

\section{Contributor Details}

Derek Johnston is Lecturer in Broadcast Literacy at Queen's University, Belfast, and the author of Haunted Seasons: Television Ghost Stories for Christmas and Horror for Halloween (Palgrave, 2015). His research is primarily concerned with 'escapist' genres, such as horror, science fiction and historical drama, and particularly their history within British media contexts. He has contributed chapters and articles to a range of journals and edited collections, including Critical Studies in Television, Networking Knowledge, Science Fiction 
Film and Television, The Routledge Companion to Science Fiction, The Liverpool Companion to World Science Fiction Film, and The Routledge Companion to the Ghost Story.

\section{Contact:}

Queen’s University Belfast, University Road, Belfast, BT7 1NN, UK.

E-mail: derek.johnston@qub.ac.uk 